\title{
EL DILEMA \\ DE JOHN STUART MILL
}

\author{
CRISTIÁN LARROULET PHILIPPI*
}

Resumen: Este artículo discute la idea de que John Stuart Mill mantuvo dos posiciones intelectuales consideradas como contradictorias. Por un lado, él propuso una epistemología radicalmente empirista en su System of Logic. Por el otro, Mill defendió la Economía Política de David Ricardo, bastante criticada desde una perspectiva empírica en su momento. Este artículo argumenta que no hay contradicción interna en Mill, ya que él postula que el método usado por la Economía Política (criticado por su apriorismo) es necesario debido a las dificultades propias del objeto de estudio. Incluso, Mill sostiene que ese es el único método posible para las ciencias sociales.

Palabras clave: J.S. Mill, metodología económica, epistemología.

Clasificación JEL: B12, B41.

Abstract: This paper discusses the idea that John Stuart Mill supported two intellectual positions which are considered to be contradictory. On one hand, he proposed a radical empiricist epistemology in his System of Logic. On the other hand, Mill defended David Ricardo's Political Economy, fairly criticized in its time from an empirical point of view. This paper argues that there is no internal contradiction in Mill, as he believes that the method used in Political Economy (criticized for being a priori) is necessary because of the difficulties that rise due to the nature of the study object. Furthermore, Mill suggests that it is the only possible method that social sciences may use.

Key words: J.S. Mill, economic methodology, epistemology.

JEL Classification: B12, B41.

* Instituto Libertad y Progreso, Santiago de Chile. Se agradecen el apoyo y los comentarios de Manuel Correia, José Díaz, Gabriel Zanotti y Leonidas Montes.

Procesos de Mercado: Revista Europea de Economía Política Vol. VII, n.. 2, Otoño 2010, pp. 89 a 108 


\begin{abstract}
«There are so many combinations - so many operating causes in Political Economy, that there is great danger in appealing to experience in favor of a particular doctrine, unless we are sure that all the causes of variation are seen and their effects duly estimated.» David Ricardo, carta a Malthus, 7 de Octubre de 1825. ${ }^{1}$

"Deduction has still an important part to play, but no longer a preponderating part, because the establishment of true principles is now becoming a matter of more difficulty than the development of proper consequences» Auguste Comte. ${ }^{2}$
\end{abstract}

En la discusión metodológica de la ciencia económica se ha planteado que John Stuart Mill tuvo muchas dificultades para reconciliar dos movimientos intelectuales a los que él se adhirió con mucha fuerza. ${ }^{3}$

Por un lado, y desde muy pequeño, Mill estuvo influenciado por la Economía Política de David Ricardo que le enseñó su padre, James Mill, amigo muy cercano y colaborador del mismo. ${ }^{4}$

1 Cfr. Ricardo (1890, p. 96).

2 Cfr. Comte $(1968,418)$ citado en Ekelund et al $(1973$, p. 386).

${ }^{3}$ El más contemporáneo de los autores que mencionan este «problema de Mill» es Douglas Wade Hands en su reconocido trabajo sobre metodología económica Reflection Without Rules: Economic Methodology and Contemporary Science Theory. Cfr. Hands (2001, p. 16). Otros autores en una línea parecida son Robert B. Ekelund, Jr. y Emilie S. Olsen: «Mill, who introduced Comte to English thought, underwent a partial conversion to his ideas, especially as they related to a broad social science. We shall demonstrate that Mill was never totally successful in compartmentalizing these ideas from his Ricardian political economy, and that Comte's influence was manifest in his economic writings» Ekelund et al. (1973, p. 384). En el ámbito castellano, Zanotti (1996, p. 5) lo formula así: «Con J.S. Mill nos encontramos ante una verdadera particularidad epistemológica. Partidario del más estricto inductivismo en ciencias naturales (concepción a la cual enriquece con sus aportes a la lógica de la inducción), aplica en cambio a la economía un método hipotético-deductivo altamente elaborado, razón por la cual se lo ha considerado, históricamente, como "apriorista", dado que sus hipótesis se quedarían colocadas como axiomas a partir de los cuales se deduce el conjunto de las leyes económicas».

${ }^{4}$ James Mill publicó un libro sobre economía política -Elements of Political Economy (1821) — en base a las lecciones que él le dio a su hijo John cuando éste tenía apenas 13 años en 1819. Cfr. Mill (1965, pp. 25-26). 
Ahora bien, la Economía Política de Ricardo es considerada por Hands (2001, p. 16) como una «with a tight deductive structure, based on a minimal number of rationally derived assumptions, and exhibiting a less-than-stellar empirical track record». Por otro lado, Mark Blaug, un destacado estudioso de la obra de Ricardo, postula que John Stuart Mill, con la publicación de sus Principles of Political Economy, le extendió la vida a la teoría ricardiana siendo que ésta ya era insostenible por su mal desempeño empírico. ${ }^{5}$ Aún más, el filósofo inglés William Whewell y el Reverendo Richard Jones, coetáneos de Mill, fieles seguidores de Francis Bacon y miembros del pequeño círculo inductivista de Cambridge, ${ }^{6}$ criticaron a Ricardo porque, según ellos, «he had reasoned upon premises which were based on only the most casual observation; and, as it happened, the deductions for which he claimed general applicability were no more than special cases». ${ }^{7}$ Según ellos, la tradición de la Economía Política iniciada por Ricardo no era inmune a la crítica que Bacon hiciera a quienes pretendían «anticipar» y no «interpretar» a la naturaleza, a los que, partiendo de unas cuantas experiencias, «vuelan» rápidamente a principios que creen inmutables. ${ }^{8}$ De este modo, el

5 Cfr. Blaug (1956). Esta tesis sería avalada, parcialmente por de Marchi (1970).

6 Puede que esta descripción de Whewell sea un tanto novedosa para los acostumbrados a clasificarlo como un «neo-kantiano» siguiendo a Butts (1973).En ese caso, ver De Marchi (1973, pp. 379-380).

7 De Marchi (1973, pp. 381-382)

8 Cfr. De Marchi y Sturges (1973, pp. 381-382). Bacon fue muy claro en el aforismo XIX: «No hay ni puede haber más que dos caminos para indagar y descubrir la verdad. El uno parte volando de los sentidos y de los hechos particulares a los axiomas más generales, y partiendo de estos principios y de lo que se cree verdad inmutable en ellos, procede a la discusión y descubrimiento de los axiomas medios (y éste es el camino en uso). El otro hace salir los axiomas de los sentidos y de los hechos particulares elevándose continua y progresivamente para llegar, en último lugar, a los principios generales; éste es el camino verdadero, pero todavía no probado» y en el XXVIII: «Es más, las anticipaciones son mucho más poderosas que las interpretaciones para conquistar nuestro asentimiento; porque sacadas de pocos ejemplos y éstos de los que se presentan más vulgarmente, se apoderan inmediatamente del entendimiento y llenan la imaginación, mientras que por el contrario las interpretaciones recogidas acá y allá de hechos muy variados y distantes entre sí no pueden herir el entendimiento de una manera súbita, de tal modo que para la opinión común forzosamente han de parecer duras y discordantes casi como los misterios de la fe.»; ambos del primer libro de su Novum Organum. 
caso parece ser que John Stuart Mill estaría apoyando una teoría económica criticada desde una perspectiva empírica.

Por el otro lado, Mill es considerado como un «empirista radical», ${ }^{9}$ para quien la fuente del conocimiento no es otra que la experiencia, la que incluso le da validez a las «ciencias formales». Mill sostendría que la única forma de evitar especulaciones inútiles es verificando las proposiciones mediante la observación de los hechos. ${ }^{10}$

Surge la pregunta, entonces, respecto a una eventual contradicción entre el Mill «economista» y el Mill «filósofo de las ciencias». Este ensayo argumenta que, después de todo, no hay una inconsistencia seria en Mill al mantenerse en los marcos de la Economía Política ricardiana. Para mostrar las bases de esta tesis se revisará brevemente la propuesta metodológica general de Mill (I), luego se expondrán algunas precisiones que Mill hace al momento de hablar de economía -o Economía Política, como se la llamaba en sus tiempos (II) - para finalizar con algunas conclusiones (III).

En el comienzo de su System of Logic, ${ }^{11}$ John Stuart Mill establece que las verdades se nos dan a conocer de dos modos, algunas de manera directa y otras de manera indirecta, esto es, a través de otras verdades $(1950$, p. 8). Al primer grupo pertenecen nuestras sensaciones corporales y nuestros sentimientos mentales, los que corresponden a conocimientos que obtenemos intuitivamente o por medio de la conciencia inmediata. Para este tipo de verdades no se requiere de ciencia alguna, ya que ninguna metodología nos permitiría corroborarlas ni, incluso,

9 «Mill was a radical empiricist» Hands (2001, p. 16). Más abajo aparecen otras citas que justifican catalogar así a Mill.

10 Cfr. Nagel (1950, p. XXXii).

11 Nos basaremos principalmente en la octava edición inglesa de su System of Logic Mill (1950) y en una edición castellana (1908). Ambos textos están abreviados. Para el desarrollo de esta sección también tomaremos citas de su Autobiography (1965). 
estar más confiados de su veracidad. En palabras de Mill, «no rules of art can render our knowledge of them more certain than it is in itself» (1950, p. 9). Por esta razón, a la lógica, en cuanto "ciencia de la prueba», 12 no le compete dicho tipo de verdades, sino que es la metafísica la encargada de revisarlos. ${ }^{13} \mathrm{El}$ segundo grupo, el de las verdades indirectas, se conforma por medio de inferencias basadas en verdades del primer grupo y del segundo. Así, la lógica se restringe sólo a este segundo grupo, ya que a ella le competen las inferencias:

The object of logic ... is to ascertain how we come by that portion of our knowledge (much the greatest portion) which is not intuitive; and by what criterion we can, in matters not self-evident, distinguish between things proved and things not proved, between what is worthy and what is unworthy of belief. (Mill 1950, p. 14).

En el caso de Mill, a diferencia de Hume, la prueba que valida la creencia (worthy of belief) va a ser siempre empírica, nunca formal, incluso cuando se trata de la geometría euclidiana o de otra ciencia estrictamente formal. No se presenta en Mill la dicotomía entre matters of facts y relation of ideas que le permitió a Hume salvar - de su duda escéptica- la necesidad universal de las proposiciones de la lógica formal y de las matemáticas. ${ }^{14}$ Mill postula que esa necesidad universal asociada a la lógica y a la matemática, incluso a cierta física de su época, le ha dado pie y popularidad a quienes postulan que «truths external to the mind may be known by intuition or consciousness, independently of observation and experience» (1965, p. 133). Esto debido a la aparente analogía entre ese tipo de verdades, que conocemos por intuición, y las de la matemática. Esta postura, ${ }^{15}$ según Mill, ha

12 «Logic is not the science of belief, but the science of proof or evidence. In so far as belief professes to be found on proof, the office of logic is to supply a test for ascertaining whether or not the belief is well grounded» (Mill 1950, p. 11).

${ }_{13}$ Cfr. Hands (2001, p. 16).

${ }_{14}$ Cfr. Hume (2007, p. 25).

15 Mill clasifica a los que la comparten como los miembros de «the ontological and "innate principles" school» en su Autobiography (1965, p. 133). 
llevado a que prejuicios y creencias muy establecidas, por el mero hecho de estar asociadas a sentimientos muy fuertes, no se hayan visto en la necesidad de ser justificadas. Así se han popularizado doctrinas falsas e instituciones que no contribuyen al progreso de la humanidad. De hecho, su System of Logic fue un intento por criticar esta corriente de pensamiento, revisando precisamente su pretendido soporte - la supuesta necesidad universal de la lógica y las matemáticas- y dando una explicación desde la experiencia para aquellas verdades que son consideradas necesarias. ${ }^{16}$ Para Mill, las sensaciones que tenemos del mundo externo es lo único que nos permite conocer, directa e indirectamente. ${ }^{17}$ Todo el conocimiento se obtiene de la experiencia y se prueba en ella. Este empirismo radical — si se lo contrasta con el de Hume- no era muy compartido en su época: ${ }^{18}$

Why are mathematics by almost all philosophers, and (by some) even those branches of natural philosophy which, through the medium of mathematics, have been converted into deductive sciences, considered to be independent of the evidence of experience and observation and characterized as systems of necessary truth? The answer I conceive to be that this character of necessity ascribed to the truths of mathematics and...the peculiar certainty attributed to them is an illusion ....[because] what apparently follows from a definition follows in reality from an implied assumption that there exist a real thing conformable thereto (Mill 1950, p. 145).

John Stuart Mill dedica una considerable fracción de System of Logic a la silogística ${ }^{19} \mathrm{y}$, como sabe de la física newtoniana y

16 Cfr. Mill (1965, p. 138). En las palabras de Nagel «Mill rejected the view that the "laws of thought" - the principles of contradiction and excluded middle- are either inherent laws of the thinking faculty or analytical propositions whose truth is involved in the meaning of their terms». (Nagel 1950, p. XXXV)

17 En System of Logic dice «...[O]f the outward world, we know and can know absolutely nothing, except the sensations which we experience from it», citado por Hands (2001, p. 17).

18 De hecho, Mill pensó que su System of Logic no iba a ser muy considerado por el público británico, aunque sí lo fue. Cfr. Mill (1965).

19 Cfr. Hands (2001, p. 17). 
de la economía ricardiana, él es consciente de que la deducción de premisas universales es ampliamente usada en las ciencias que él considera como legítimas. Sin embargo, nadie es capaz de tener sensaciones de universales, experimentar leyes universales. ¿De dónde obtienen, entonces, su validez estas deducciones silogísticas propias de la mecánica newtoniana y de la economía política ricardiana? La respuesta de Mill es que:

All inference is from particulars to particulars: general propositions are merely registers of such inferences already made... the major premise of a syllogism, consequently, is a formula of this description... the real logical antecedent, or premise, being the particular facts from which the general proposition was collected by induction. Those facts ... may have been forgotten... [but] when known, were considered to warrant a given inference (Mill 1950, p. 127).

Así, el fundamento de verdad de las deducciones silogísticas no está en su sola corrección o consistencia, sino también en la veracidad de las inducciones que permitieron formular la premisa mayor de dichos silogismos. La ciencia siempre depende de la inducción para ser cierta - y no sólo correcta o consistentepor lo que la inducción es el más importante estudio de la lógica: «Toda inferencia, toda prueba y por tanto todo descubrimiento de verdades no evidentes por sí mismas, consiste en inducciones» (Mill 1908, p. 90). ${ }^{20}$ Ahora bien, ¿qué es lo que le da el fundamento a la inducción? El postulado de que «lo que sucede una vez sucederá siempre» dice Mill21 (1908, p. 96); pero, como nada se conoce si no es a través de la experiencia, dicho postulado no puede ser demostrado sin recurrir a ella: «la observación de la naturaleza confirma el postulado» (Ibíd.). O sea, el postulado mismo es resultado de la inducción. Esto degenera en

${ }^{20}$ Esto fue lo que llevó a Mill a postergar, por un tiempo, la redacción de la sección sobre la deducción de su System of Logic —el llamado «problem of Reasoning»— para dilucidar primero el problema de la inducción «on the ground that is necessary to obtain premises before we can reason from them» (Mill 1965, p. 97).

${ }^{21}$ Lo que se expresa, típicamente, con el adagio Natura non facit saltus. 
un círculo vicioso si lo que se está intentado es categorizar con una necesidad universal los conocimientos obtenidos por medio de la deducción, pero Mill no está buscando eso. En palabras simples, ninguna proposición tiene necesidad universal en sentido estricto, todo conocimiento es hipotético, incluso el deductivo, porque éste se basa en una inducción, que, como todo conocimiento, carece de estricta validez universal.

Al momento de clasificar a las distintas ciencias, Mill refleja de manera prístina el impacto que tuvo en su pensamiento la física mecánica de Newton y, en particular, en la forma de la llamada Ley de Composición de las Causas, la que establece que el efecto total de un conjunto de causas actuando simultáneamente es igual a la suma de los efectos de cada causa considerada de manera aislada. ${ }^{22}$ Esta ley, según Mill, sí se cumple en los fenómenos mecánicos y en la economía, pero no se da en la química - no en la de su época al menos- donde «los compuestos tienen propiedades que no son la suma de las propiedades de los componentes» (Mill 1908, p. 111). La primera división de las ciencias que hace Mill, entonces, es entre las ciencias en las que sí se cumple la Ley de Composición de las Causas - las «deductivas»-y las que no, denominando a estas últimas «experimentales» $\mathrm{O}$ «heteropáticas». ${ }^{23}$ Mill va a llevar la importancia de la ley de composición más lejos aún, afirmando que incluso:

[A] unque hay leyes heteropáticas, que surgen por infracción del principio de composición de causas, estas leyes se combinan entre sí según el referido principio de composición de causas: las leyes de la química y de la fisiología (heteropáticas) se combinan conforme a dicho principio de composición; y es por esto que se pueden estudiar deductivamente los más complejos fenómenos de la química y de la vida, del espíritu y de la sociedad, fundándose en los más sencillos (Mill 1908, p. 112).

22 Cfr. Mill (1965, p. 98) y (1908, pp. 110-113).

23 Cfr. Hands (2001, p. 18) y Mill (1908, pp. 111-112). Nótese que en la división de las ciencias que Mill postula no entra el criterio de «inductiva» $\mathrm{O}$ "no inductiva», ya que para él toda ciencia es inductiva. 
Esta propuesta, muy optimista al decir de algunos, ${ }^{24}$ le facilita considerablemente la tarea al científico, ya que le da carta de ciudadanía al uso de pensamientos deductivos como el de la matemática - siempre fundado en buenas inducciones eso síen ciencias que tratan materias tan complejas como las ciencias sociales. En otras palabras, se elude un grueso problema al simplemente suponer que las distintas causas que inciden en el fenómeno a investigar se pueden estudiar aisladamente, para luego «sumarlas». Y, si nos las tenemos que ver con leyes que no han podido ser formadas de este modo, al menos podemos combinar dichas leyes de este modo. En la discusión metodológica de la economía esta posición de Mill ha sido designada como «individualismo metodológico». ${ }^{25}$

${ }^{24}$ En las primeras páginas de su famoso ensayo de 1937, «Teoría tradicional y teoría crítica», Horkheimer caracterizará a la «teoría tradicional» — para luego criticarla - como aquella donde «la deducción, tal como se la usa en las matemáticas, sería aplicable a la totalidad de las ciencias. El orden del mundo se abre a una conexión deductiva de pensamientos»; muy en la línea de la tercera regla del método científico que propuso Descartes en su Discurso del método. En palabras de Habermas, continuador en cierta medida de la escuela fundada, entre otros, por Horkheimer en Frankfurt: «Con esta anticipación, el acontecer social es entendido como un plexo funcional de regularidades empíricas» $(2007$, p. 22). El asunto es de dónde sabemos que el mundo tiene esa estructura «legaliforme», regular. Esta pregunta es un problema considerable para todo aquel que, como Mill, pretenda basar todo el conocimiento humano en la experiencia, sin recurrir a una peculiar «forma de la experiencia» o un supuesto teológico o filosófico sobre la estructura última de la realidad. Pero no es sólo dentro de los marcos de la Escuela de Frankfurt donde se cuestiona esta simplificación aducida por Mill. Desde otra escuela filosófica, Emile Durkheim también criticaría este presupuesto de Mill, ya que para el francés el todo no es igual a la suma de sus partes: «el hecho social es distinto de sus repercusiones individuales» (1964, p. 35). Desde una perspectiva más contemporánea, ahora sí, la Teoría de Sistemas propuesta por Niklas Luhmann también cuestionará el supuesto milliano, aunque ya no usando la distinción todo/partes de Durkheim sino la distinción sistema/ambiente. Cfr. Rodríguez y Arnold (2007, p. 83).

${ }^{25}$ El locus clásico en la obra de Mill es: «The laws of the phenomena of society are and can be nothing but the laws of the actions and passions of human beings united together in the social state. Men, however, in a state of society are still men; their actions and passions are obedient to the laws of individual human nature. Men are not, when brought together, converted into another kind of substance with different properties, as hydrogen and oxygen are different from water... In social phenomena the composition of causes is the universal law (Mill 1950, pp. 324-325). Cfr. Hands (2001, p. 21). Hausman, plantea que «Mill never justifies his claim that 
John Stuart Mill recurre a una segunda división de las ciencias, donde el énfasis ahora está puesto en la cantidad de causas que están detrás del fenómeno que nos interesa estudiar. Si para cada efecto hay una sola causa, parece plausible que por medio de alguno de «los cuatro métodos de experimentación» ${ }^{26}$ propuestos por Mill podamos identificar dicha causa. Ahora bien, el asunto se complica si consideramos que para cada efecto puede haber un conjunto de causas. En este caso no es seguro que podamos llegar a conclusiones acabadas usando los métodos mencionados. La pluralidad de las causas es también la razón por la que Mill prefiere hablar de que «las causas obran como tendencias, y que su efecto se vuelve ostensible si no está contrariado» (1908, p. 136). Él prefiere el término «tendencia» para evitar hablar de leyes con excepciones: «en realidad las excepciones no existen: lo único que pasa es que a veces el efecto de una causa está absolutamente enmascarado por el de otra» (1908, p. 137). Así, la pluralidad de las causas lleva a una segunda división de las ciencias, una división por métodos:

Los efectos compuestos por resultados de muchas causas pueden ser estudiados de dos modos: a priori, deduciéndolos de las leyes que rigen a cada efecto aislado, o a posteriori, observando el conjunto de causas como una sola, ya siempre igual, o bien con variaciones producidas experimentalmente (1908, p. 136).

Sin embargo, en ciencias como las médicas y las sociales «el método experimental muy poco puede hacer» ya que:

\footnotetext{
the phenomena of society are mechanical» (1981, p. 380), refiriéndose con «mechanical» a lo que nosotros hemos llamado «deductivas».

Un autor contemporáneo que estaría a favor de esta postura de Mill y, por lo tanto, en contra de los autores mencionados en la nota al pie anterior, es Karl Popper: «the belief in the empirical existence of social wholes or collectives, which may be described as naïve collectivism, has to be replaced by the demand that social phenomena, including collectives, should be analysed in terms of individuals and their actions and relations» (2002, p. 459).

${ }^{26}$ Cfr. Mill (1908, pp. 116-125): Los métodos los llama Mill «de la concordancia», «de la diferencia» (1908, p. 116), «unido de concordancia y diferencia» (1908, p. 120) $\mathrm{y} «$ de residuos» (1908, p. 121).
} 
hay en ellas casi sin límites pluralidad de causas y mezcla de efectos, de suerte que, en las ciencias sociales, es irrisorio aplicar el método experimental [a posteriori], dada la complejidad y la variabilidad incontable de los fenómenos, y por lo mismo lo único que puede aplicarse es el método deductivo [a priori], infiriendo para lo más complejo lo que se sabe de lo no complicado (1908, p. 139).

En el método deductivo el asunto está en obtener las leyes de cada una de las causas que concurren al generar el efecto que estamos estudiando. Ahora bien, este método deductivo o a priori consta de tres partes o etapas: La inducción directa, el raciocinio y la verificación. Tiene que haber, como primer momento, una inducción directa para poder obtener la ley de cada causa relevante:

Thus if the subject be social or historical phenomena, the premises of the deductive method must be the laws of the which determine that class of phenomena, and those causes are human actions, together with the general outward circumstances under the influence of which mankind are placed and which constitute man's position on the earth... Some of these general truths [causes] will naturally be obtained by observation and experiment, others by deduction; the more complex laws of human action, for example, may be deduced from the simpler ones, but the simple or elementary laws will always, and necessarily, have been obtained by a directly inductive process (Mill 1950, p. 253).

Después de haber obtenido satisfactoriamente las leyes de las distintas causas en la primera etapa, en la segunda etapa se trata de «calcular» los efectos que las distintas combinaciones de estas causas producirían (Mill 1950, p. 254). Cuanto más exactas sean las leyes obtenidas en la primera etapa, más exacta va a ser la predicción de los efectos que las distintas combinaciones de dichas leyes producen. Ahora bien, se pregunta Mill «When in every single instance, a multitude, often an unknown multitude, of agencies are clashing and combining, what security have we that in our computation a priori we have taken all these into our reckoning?» (1950, p. 255). Aquí es donde entra la tercera etapa, 
en la que verificamos si nuestras conclusiones coinciden con los hechos observables. No pudimos derivar las leyes simples de los hechos observables cuando se trataba de fenómenos muy complejos, pero sí podemos hacer uso de esos hechos para verificar nuestra teoría:

It is worth remarking that complex instances which would have been of no use for the discovery of the simple laws into which we ultimately analyze their phenomena, nevertheless, when they have served to verify the analysis, become additional evidence of the laws themselves (1950, p. 256).

Se puede concluir, entonces, que el método a priori del que habla Mill no busca «anticipar» la naturaleza, no es teoría desarraigada de lo empírico, no es metafísica. Es, simplemente, el método empírico que Mill propone cuando se trata de estudiar fenómenos muy complejos como los que tratan las Ciencias Sociales. ${ }^{27}$ En el método a priori de Mill sigue siendo la experiencia el origen y la prueba de validez del conocimiento, no hay abdicación del empirismo.

\section{II}

En su «On the definition of Political Economy; and the Method of Investigation Proper to It», ${ }^{28}$ escrito entre 1831 y 1833, pero publicado en 1836 para la radical London and Westminster Review, ${ }^{29}$ John Stuart Mill plantea que al hombre, en cuanto sujeto moral, lo pueden estudiar las ciencias morales bajo tres hipótesis diferentes: estudiar "what belongs to man considered individually» — rol de la filosofía mental pura- estudiarlo «consider[ing] him

27 Zanotti (1996, p. 8) plantea que, en definitiva, lo que propone Mill es simplemente lo que hoy se conoce como el método hipotético deductivo: «Vemos entonces que Mill aplica el término a priori para lo que hoy es el método hipotéticodeductivo».

${ }^{28}$ En esta sección, nos basaremos principalmente en su «On the definition of Political Economy; and the Method of Investigation Proper to It» (2000).

${ }^{29}$ Cfr. Whitaker (1975, p. 1.036). 
as coming into contact with other individuals - rol de la éticao estudiarlo «as living in a state of society» (2000, pp. 95-96). Esta última hipótesis de estudio es la que le corresponde a la política especulativa. ${ }^{30}$ Esta ciencia, claro está, depende de las otras dos, ya que recurrirá a las leyes de ellas (que tratan fenómenos más elementales), añadiendo las suyas propias, para explicar los fenómenos que le competen. Ahora bien, Mill plantea que un nombre más apropiado para esta ciencia es el de social economy ¿Cuál es la relación entre ésta y la political economy? La ciencia económica, para Mill, es una rama de la social economy, que sólo toma un aspecto de ella. Aquí tal vez valga la pena citarlo in extenso:

It does not treat of the whole of man's nature as modified by the social state, nor of the whole conduct of man in society. It is concerned with him solely as a being who desires to possess wealth, and who is capable of judging of the comparative efficacy of means for obtaining that end. It predicts only such of the phenomena of the social state as take place in consequence of the pursuit of wealth. It makes entire abstraction of every other human passion or motive; except those which may be regarded as perpetually antagonizing principles to the desire of wealth, namely, aversion to labour, and desire of the present enjoyment of costly indulgences... Political Economy considers mankind as occupied solely in acquiring and consuming wealth; and aims at showing what is the course of action into which mankind, living in a state of society, would be impelled, if that motive, except in the degree in which it is checked by the two perpetual counter-motives alcove adverted to, were absolute ruler of all their actions... Not that any political economist was ever so absurd as to suppose that mankind are really thus constituted, but because this is the mode in which science must necessarily proceed. When an effect depends upon a concurrence of causes, those causes must be studied one at a time, and their laws separately investigated, if we wish, through the causes, to obtain the power

30 Especulativa en contraste con la política entendida como «arte de gobernar», que, como todo arte en el sistema milliano, debe estar basado en una ciencia, la que, en este caso, es la política especulativa. 
of either predicting or controlling the effect... In order to judge how he [man in society] will act under the variety of desires and aversions which are concurrently operating upon him, we must know how he would act under the exclusive influence of each one in particular... there are also certain departments of human affairs, in which the acquisition of wealth is the main and acknowledged end. It is only of these that Political Economy takes notice. The manner in which it necessarily proceeds is that of treating the main and acknowledged end as if it were the sole end; which, of all hypotheses equally simple, is the nearest to the truth. The political economist inquires, what are the actions which would be produced by this desire, if, within the departments in question, it were unimpeded by any other. In this way a nearer approximation is obtained than would otherwise be practicable, to the real order of human affairs in those departments. This approximation is then to be corrected by making proper allowance for the effects of any impulses of a different description, which can be shown to interfere with the result in any particular case. (2000, pp. 97-99).

En la cita se pueden apreciar la primera y la segunda etapa del método deductivo: (1) de alguna manera se determinó (¿mediante una inducción directa?) la ley de la búsqueda de la riqueza al menor costo posible como una «motivación»" ${ }^{31}$ crucial en la naturaleza del hombre, y (2) la economía ya se ha encargado de «calcular» (mediante un raciocinio matemático) el efecto de la combinación entre esa causa y otras que posiblemente entren en juego según el caso (making the proper allowance). En otras palabras, la economía sí utiliza el método deductivo o a priori, ${ }^{32}$ el que consiste en razonar desde supuestos, y no desde hechos, tal como lo hace la geometría. Ésta define arbitrariamente el concepto «línea» como «lo que tiene longitud pero no anchura», aún cuando nunca nadie

31 Concepto análogo al de «fuerza» en la mecánica newtoniana.

32 «By the method a priori we mean (what has commonly been meant) reasoning from an assumed hypothesis; which is not a practice confined to mathematics, but is of the essence of all science which admits of general reasoning at all... In the definition which we have attempted to frame of the science of Political Economy, we have characterized it as essentially an abstract science, and its method as the method a priori» (Mill 2000, p. 101). 
haya visto realmente una línea, pero la validez de sus conclusiones acerca de la línea se la da la experiencia, en la que trabajamos con líneas «aproximadas», o sea, reales. En la ciencia económica este método es legítimo, ya que en su primera etapa los supuestos surgen de la experiencia y, en su tercera etapa, si las conclusiones se validan en la experiencia, ${ }^{33}$ con hombres «reales» y no con el homo economicus, ya que éste - como las líneas con las que trabaja la geometría - no se nos da en la experiencia. Aún más, la economía, como ya se dijo, no puede usar el método a posteriori para hacer sus predicciones desde cero, ${ }^{34}$ ya que trata fenómenos multi-causales los cuales permiten pocas posibilidades de hacer experimentos, por lo que no puede depender del experimentum crucis que divulgó Bacon (Mill 2000, p. 103):

it is vain to hope that truth can be arrived at, either in Political Economy or in any other department of the social science, while we look at the facts in the concrete, clothed in all the complexity with which nature has surrounded them, and endeavour to elicit a general law by a process of induction from a comparison of details; there remains no other method than the a priori one, or that of «abstract speculation» (Mill 2000, pp. 104-105).

A nuestro juicio, hay dos razones por las que se le podría acusar a Mill de no ser un empirista coherente; ambas coinciden con los dos momentos en que su metodología vincula lo general con lo particular, a saber, la primera y la segunda etapa.

33 «To verify the hypothesis itself $a$ posteriori, that is, to examine whether the facts of any actual case are in accordance with it, is no part of the business of science at all, but of the application of science» (Mill 2000, p. 101).

34 «We affirm that the method a posteriori, or that of specific experience, is altogether inefficacious in those sciences, as a means of arriving at any considerable body of valuable truth; though it admits of being usefully applied in aid of the method $a$ priori, and even forms an indispensable supplement to it» (Mill 2000, p. 103). Otra forma de ponerlo es «direct induction will not yield conclusive results in situations where many conflicting causes are at work, especially in nonexperimental situations» (Whitaker 1975, p. 1.039). 
En la primera, la cuestión sería de dónde sabe Mill que la ley de la búsqueda de la riqueza (the desire of wealth) es un elemento esencial de la naturaleza del hombre (the main and acknowledged end); tan esencial que es la hipótesis más simple y que más nos acerca a los hechos observables que le competen a la economía (the nearest to the truth).

En la segunda, el problema surge al momento de hacer una predicción de un fenómeno particular, al momento de «aplicar la ciencia»: ¿Cómo sabe el economista cuáles otras causas -y en qué proporción- están en juego, «enmascarando» a la más básica (the desire of wealth)? Esto es algo que el economista requiere para poder «calcular» las consecuencias de la interacción de las distintas causas. Pero este problema existe sólo si olvidamos la tercera etapa del método deductivo. ${ }^{35}$

Se podría decir que ambos problemas son parte del mismo -el de cuál es la validez empírica de la economía- y que podrían tener una solución evolucionista: es el mismo desarrollo de la ciencia económica, el correcto despliegue de las tres etapas del método, lo que garantizará que la economía no sea una mera especulación, sino una ciencia propiamente tal. Esto parecer estar presente en Mill, en su mirada positiva sobre la ciencia empírica y en su característico optimismo decimonónico respecto del progreso de la humanidad. Sin embargo, parecieran haber también indicios de soluciones más específicas que surgen de la naturaleza del fenómeno en cuestión. Un indicio podría venir del hecho de que el científico, en el caso de la economía, comparte la misma naturaleza que el objeto de estudio:

These causes are, laws of human nature, and external circumstances capable of exciting the human will to action. The desires

\footnotetext{
35 «Although, therefore, a philosopher be convinced that no general truths can be attained in the affairs of nations by the a posteriori road, it does not the less behove him, according to the measure of his opportunities, to sift and scrutinize the details of every specific experiment. Without this, he may be an excellent professor of abstract science...If, however, he does no more than this, he must rest contented to take no share in practical politics; to have no opinion, or to hold it with extreme modesty, on the applications which should be made of his doctrines to existing circumstances» (Mill 2000, pp. 108-109).
} 
of man, and the nature of the conduct to which they prompt him, are within the reach of our observation. We can also observe what are the objects which excite those desires. The materials of this knowledge every one can principally collect within himself; with reasonable consideration of the differences, of which experience discloses to him the existence, between himself and other people. Knowing therefore accurately the properties of the substances concerned, we may reason with as much certainty as in the most demonstrative parts of physics from any assumed set of circumstances (Mill 2000, pp. 105, el destacado es nuestro).

Pero no sería apropiado creer que en la introspección se encuentra la fuente, por así decirlo, de las verdades necesarias del hombre. La cuestión radica ahora en qué tan buena es la ley de la búsqueda de la riqueza como hipótesis fundamental, habiéndola adquirido por medio de la experiencia, ya que eso es la introspección. Un pasaje de los Principles of Political Economy puede iluminar la posición que toma Mill en cuanto a esta hipótesis fundamental. Ya que la posible crítica que hemos mencionado se basa en la sospecha de que Mill no justifica empíricamente la elección de la ley de la búsqueda de la riqueza como hipótesis fundamental, $y$, dado que es la propia introspección el origen empírico de esta elección, ante esta falta de ortodoxia empirista permanece la sospecha de qué tan dispuesto está Mill a abandonar dicha hipótesis si se la hallara contraria a los hechos. En el siguiente pasaje, Mill designa a la ley de la búsqueda de la riqueza ${ }^{36}$ como competencia (competition) y al resto de las circunstancias atenuantes - o disturbing causes - como costumbre (custom):

Political economists ... have been accustomed to lay almost exclusive stress upon the first of [two] agencies [competition and custom]; to exaggerate the effect of competition, and to take into little account the other and conflicting principle. They are apt to express themselves as if they thought that competition actually does, in all cases, whatever it can be shown to be the tendency of competition to do. This is partly intelligible, if we consider that

\footnotetext{
36 Sus implicancias más bien.
} 
only through the principle of competition has political economy any pretension to the character of a science... But it would be a great misconception of the actual course of human affairs to suppose that competition exercises in fact this unlimited sway...

Competition, in fact, has only become in any considerable degree the governing principle of contracts, at a comparatively modern period. The further we look back into history, the more we see all transactions and engagements under the influence of fixed customs (2009, pp. 204-205).

Así, si existe un cierto compromiso con los supuestos que toma de Ricardo, Mill es consciente de que estos supuestos son contingentes. De hecho, así como antes no eran muy útiles, en el futuro pueden no serlo tampoco. En ese caso, la Economía Políti$\mathrm{ca}$, para poder seguir siendo una ciencia (independiente), tendría que cambiar de hipótesis. En el fondo, Mill sigue siendo un «empirista radical» en el sentido de que todo, absolutamente todo, conocimiento nace y se prueba en la experiencia. Pero en materias complejas, como en las ciencias sociales, nuestro conocimiento siempre va a ser precario. La única forma de avanzar que tenemos es mediante las tres etapas del método deductivo, sin que por el hecho de verificar nuestras predicciones creamos que hemos alcanzado leyes universales necesarias, ya que eso no es posible. En las ciencias sociales nos vemos «obligados» al uso del método deductivo, lo que no significa verse obligado a olvidarse de la experiencia. El quid del asunto radica en mantener lo más posible nuestras teorías "cerca» de la experiencia, ya sea cuando las formulamos o cuando las verificamos. Es por esto que, en última instancia, Mill hace un llamado a un "escepticismo mitigado" con respecto a las conclusiones que obtiene la ciencia:

Effects are commonly determined by a concurrence of causes. If we have overlooked any one cause, we may reason justly from all the others, and only be the further wrong. Our premises will be true, and our reasoning correct, and yet the result of no value in the particular case. There is, therefore, almost always room for a modest doubt as to our practical conclusions (2000, pp. 112, el destacado es nuestro). 
En el fondo, un empirista siempre creerá que cuanto más de empirie tengan nuestras ideas, más ciertas serán, y cuanto menos tengan - sea por dificultades propias de la materia, por falta de instrumentos u otra razón- más hipotético será su carácter. No es contradicción lo que vemos en Mill, sino más bien cierta agudeza: la lucidez para captar las formas por las que nuestro conocimiento - siempre hipotético, y más cuanto menos empírico espuede avanzar sin tranzar su carácter científico. El que John Stuart Mill le dé tanto énfasis a los supuestos y las deducciones no es manifestación de una contradicción interna, no es un «lastre ricardiano» ni una abdicación empirista, sino la muestra de su perspicacia, de su falta de ingenuidad al momento de tratar con fenómenos complejos. Es una salida, bastante original y dentro de los marcos del empirismo, al problema metodológico que presentan las ciencias multi-causales.

\section{REFERENCIAS BIBLIOGRÁFICAS}

Blaug, M. (1956): «The Empirical Content of Ricardian Economics», Journal of Political Economy, Vol. LXIV, pp. 41-58.

ButTs, R. (1973): «Whewell's Logic of Induction,» en R.N. Giere and R.S. Westfall (eds.), Foundations of Scientific Method: The Nineteenth Century, Bloomington, Indiana University Press, pp. 53-85.

Comte, A. (1968): System of Positive Polity, Vol. 1, New York: Burt Franklin Reprint.

DE MARChI, N.B. (1970): «The Empirical Content and Longevity of Ricardian Economics», Economica Vol. 37, N. ํ 147, pp. 257-76.

De Marchi, N.B. y Sturges, R.P. (1973): «Malthus and Ricardo's Inductivist Critics: Four Letters to William Whewell», Economica, Vol. 40, ․․ 160, pp. 379-393.

DurKHeIM, E. (1964): Las reglas del método sociológico, Buenos Aires: Editorial Dédalo.

Ekelund, R.B., Jr. y Olsen, E.S. (1973): «Comte, Mill, and Cairnes: The Positivist-Empiricist Interlude in Late Classical Economics», Journal of Economic Issues, Vol. 7, N. 3, pp. 383-416. 
Habermas, J. (2007): La lógica de las ciencias sociales, Madrid: Tecnos. Hands, D.W. (2001): Reflection Without Rules: Economic Methodology and Contemporary Science Theory, Cambridge: Cambridge University Press.

Hausman, D. (1981): «John Stuart Mill's Philosophy of Economics», Philosophy of Science Vol. 48, N. 3, pp. 363-85.

Mill, J.S. (1908): Resumen sintético del Sistema de Lógica, París: Lib. De la Vida de Ch. Bouret.

- (1950): Philosophy of Scientific Method, New York: Hafner Publishing Co. [Versión resumida de la octava edición $A$ system of Logic (New York, 1881)]

- (1965): «Autobiography», en Essential works of John Stuart Mill, New York: Bantam Matrix Editions.

- (2000): «On the definition of Political Economy; and the Method of Investigation Proper to It» en Essays on Some Unsettled Questions of Political Economy, Kitchener: Batoche Books [tomada de la segunda edición de 1874].

- (2009): Principles Of Political Economy, Project Gutenberg EBook 30107-pdf. Versión de New York: D. Appleton And Company, 1885.

NAGel, E. (1950): «Introduction» en John Stuart Mill, Philosophy of Scientific Method, New York: Hafner Publishing Co.

Popper, K. (2002): «Prediction and Prophecy in the Social Sciences», en Conjectures and Refutations, New York: Routledge.

Ricardo, D. (1890): Letters of Ricardo to Malthus, London: Oxford University Press.

Rodríguez, D. y ARnold, M. (2007): Sociedad y teoría de sistemas, Santiago: Editorial Universitaria.

WhitAKer, J.K. (1975): «John Stuart Mill's Methodology», The Journal of Political Economy, Vol. 83, N. 5, pp. 1.033-1.049.

ZANOTTI, G.J. (1996): «Caminos abiertos, un análisis filosófico de la epistemología de la economía», primera parte, Libertas, N.. 25 . 